\title{
MicroED and cannabinoid research
}

\author{
Crist N. Filer ${ }^{1,2}$
}

\begin{abstract}
MicroED has recently emerged as a convenient and powerful tool for the unequivocal structure determination of small molecules and it could likely be used in cannabinoid research as well.
\end{abstract}

Keywords: Cannabis, Cannabinoid, MicroED

\section{Dear Editor,}

Despite the growing application of other spectroscopic tools such as nuclear magnetic resonance (NMR) and Raman spectroscopy, X-ray crystallography is still widely regarded as the definitive gold standard for organic molecule structure determination. However, in the case of cannabinoid research this method has not been fully exploited. A search of the SciFinder ${ }^{\circ}$ chemistry database produced over 42,000 published articles with the search term "cannabinoid." However, less than one percent of these publications utilized X-ray crystallography as an analytical tool and most of those few reports employed it to structure elucidate either synthetic cannabinoids (Lu et al. 2005) or Cannabis enzyme systems (Shoyama et al. 2005). There have been very few instances where $\mathrm{X}$-ray crystallography was used to characterize a natural product phytocannabinoid of the growing Cannabis collection. One example was the structure determination of cannabidiol, first elegantly deciphered by Mechoulam in 1963 with a cogent analysis of NMR chemical shifts and coupling constants (Mechoulam and Shvo 1963). However, it took more than another decade before publication of the conclusive X-ray crystal confirmation of the cannabidiol structure (Jones et al. 1977). With X-ray crystallography often regarded as much an art as science, the explanation for such a delay is perhaps simple. Since many cannabinoids are relatively lower melting solids, the challenge of obtaining appropriately large crystals for conventional X-ray crystallography has been a practical

\footnotetext{
Correspondence: crist.filer@perkinelmer.com

${ }^{1}$ PerkinElmer Health Sciences Inc., 940 Winter Street, Waltham, MA 02451, USA

${ }^{2}$ PerkinElmer, 549 Albany St, Boston, MA 02118, USA
}

limitation and the likely reason for its lack of routine use. Even in the rare case of higher melting (184-185 ${ }^{\circ} \mathrm{C}$ ) delta-9-tetrahydrocannabinolic acid B and its X-ray structural determination (Rosenqvist and Ottersen 1975), the authors reported that a suitable prismatic crystal of dimensions $0.45 \times 0.30 \times 0.12 \mathrm{~mm}$ was required and obtained, but only after "slow evaporation of a chloroform solution."

However, it is possible that with the advent of a very new technical adaptation, crystallography may soon become a more routine analytical method for cannabinoid characterization. First, some background information is useful. In 2013 using an electron cryo-microscope with a diminished electron beam (to avoid crystal damage), Gonen and Nannenga merged it with an improved data collection system and termed this hybrid technology "microcrystal electron diffraction" or MicroED (Nannenga 2020). With MicroED, no longer were arduously obtained large crystals necessary for analysis. Even seemingly amorphous powders often contained enough microcrystals of a substance to support this new method. Since its discovery, MicroEd has become an exceptionally useful tool for the structural analysis of biomolecules like proteins (Nannenga and Gonen 2019). However, importantly for cannabinoid research, a technical breakthrough has recently occurred for MicroED. The application of this powerful method has now been extended to small molecules as well (Jones et al. 2018; Nguyen and Gonen 2020). Diverse structures such as acetaminophen, biotin, brucine, carbamazepine, cinchonine, ibuprofen, progesterone, and even heterogeneous mixtures of these have been structurally analyzed to angstrom resolution with this new method.

(c) The Author(s). 2021 Open Access This article is licensed under a Creative Commons Attribution 4.0 International License, which permits use, sharing, adaptation, distribution and reproduction in any medium or format, as long as you give appropriate credit to the original author(s) and the source, provide a link to the Creative Commons licence, and indicate if changes were made. The images or other third party material in this article are included in the article's Creative Commons licence, unless indicated otherwise in a credit line to the material. If material is not included in the article's Creative Commons licence and your intended use is not permitted by statutory regulation or exceeds the permitted use, you will need to obtain permission directly from the copyright holder. To view a copy of this licence, visit http://creativecommons.org/licenses/by/4.0/. 
MicroED would seem to be an entirely new paradigm and transformational technique for the rapid and unambiguous structure determination of small molecules. A literature search revealed that MicroED has not yet been applied to cannabinoid research but it could likely be. However, practitioners have noted that despite its impressive results to date, "the MicroED method has largely gone unnoticed in the small molecule communities" (Jones et al. 2018). It is the purpose of this note to heighten awareness of the potential application of MicroED in cannabinoid research.

\section{Abbreviations}

MicroED: Microcrystal electron diffraction; NMR: Nuclear magnetic resonance

\section{Acknowledgements}

Not applicable.

\section{Author's contributions}

CF prepared the manuscript. The author read and approved the final manuscript.

\section{Funding}

None.

Availability of data and materials Not applicable.

\section{Declarations}

Ethics approval and consent to participate

Not applicable.

\section{Consent for publication}

Not applicable.

\section{Competing interests}

The author declares that he has no competing interest.

Received: 1 April 2021 Accepted: 30 April 2021

Published online: 11 May 2021

\section{References}

Jones CG, Martynowycz MW, Hattne J, Fulton TJ, Stoltz BM, Rodriguez JA, et al. The CryoEM method MicroED as a powerful tool for small molecule structure determination. ACS Central Sci. 2018;4(11):1587-92. https://doi.org/10.1021/a cscentsci.8b00760.

Jones PG, Falvello L, Kennard O, Sheldrick GM, et al. Cannabidiol. Acta Crystallographica. 1977;B33:3211-4.

Lu D, Meng Z, Thakur GA, Fan P, Steed J, Tartal CL, et al. Adamantyl cannabinoids: a novel class of cannabinergic ligands. J Med Chem. 2005; 48(14):4576-85. https://doi.org/10.1021/jm058175c.

Mechoulam R, Shvo Y. Hashish - I. The structure of cannabidiol. Tetrahedron. 1963;19(12):2073-8. https://doi.org/10.1016/0040-4020(63)85022-X.

Nannenga BL. MicroED methodology and development. Structural Dyn. 2020;7: Article 014304

Nannenga BL, Gonen T. The cryo-EM method microcrystal electron diffraction (MicroED). Nature Methods. 2019;16(5):369-79. https://doi.org/10.1038/s41 592-019-0395-x

Nguyen C, Gonen T. Beyond protein structure determination with MicroED. Curr Opin Struct Biol. 2020;64:51-8. https://doi.org/10.1016/j.sbi.2020.05.018.

Rosenqvist $\mathrm{E}$, Ottersen $\mathrm{T}$. The crystal and molecular structure of delta-9tetrahydrocannabinolic acid B. Acta Chemica Scandinavica B. 1975;B29:379-84.

Shoyama Y, Takeuchi A, Taura F, Tamada T, Adachi M, Kuroki R, et al. Crystallization of delta-1-tetrahydrocannabinolic acid (THCA) synthase from Cannabis sativa. Acta Crystallographica Section F. 2005;61 (8):799-801. https:// doi.org/10.1107/S1744309105023365.

\section{Publisher's Note}

Springer Nature remains neutral with regard to jurisdictional claims in published maps and institutional affiliations.
Ready to submit your research? Choose BMC and benefit from:

- fast, convenient online submission

- thorough peer review by experienced researchers in your field

- rapid publication on acceptance

- support for research data, including large and complex data types

- gold Open Access which fosters wider collaboration and increased citations

- maximum visibility for your research: over $100 \mathrm{M}$ website views per year

At BMC, research is always in progress.

Learn more biomedcentral.com/submissions 